\title{
Analisis Kemampuan Berpikir Tingkat Tinggi Mahasiswa (Higher Order Thinking) dalam Menyelesaikan Soal Konsep Optika melalui Model Problem Based Learning
}

\author{
Nurhayati $^{\text {a) }}$, Lia Angraeni ${ }^{\text {b) }}$ \\ Program Studi Pendidikan Fisika, Fakultas Pendidikan MIPA dan Teknologi, IKIP PGRI Pontianak

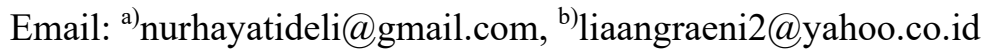

\begin{abstract}
This study aims to describe the ability of higher order thinking students in solving the problem of the concept of optics after given the learning with problem-based learning model. This research uses a descriptive method with quantitative approach. The subjects of the research are students of the second semester of physics education study program, amounting to 19 people. Data collection techniques used are two tier multiple choice shaped test consisting of eight questions include the level of analyzing, evaluating and creating. Based on the results of data analysis, it is known that the ability of high-level thinking of students in optical learning has enough categories with the following details: (1) The percentage of students who have excellent high-level thinking skills is $15.79 \%$, good category of $31.58 \%$, enough category of $42.11 \%$, and category less than $10.53 \%$; (2) The percentage of student ability in answer about level of analyze equal to $68.42 \%$, student ability in answer about evaluation level $57.89 \%$ and equal to $53.51 \%$ for student ability in answer level question create.
\end{abstract}

Keywords: higher order thinking, optics, problem-based learning model

\begin{abstract}
Abstrak
Penelitian ini bertujuan untuk mendeskripsikan kemampuan berpikir tingkat tinggi mahasiswa (higher order thinking) dalam menyelesaikan soal konsep optika setelah diberikan pembelajaran dengan model problem based learning. Metode penelitian yang digunakan adalah metode deskriptif dengan pendekatan kuantitatif. Subjek penelitian yaitu mahasiswa semester II program studi pendidikan fisika yang berjumlah 19 orang. Teknik pengumpulan data yang digunakan adalah tes berbentuk two tier multiple choice yang terdiri dari delapan soal meliputi tingkatan menganalisis, mengevaluasi dan mencipta. Berdasarkan hasil analisis data, diketahui bahwa kemampuan berpikir tingkat tinggi mahasiswa dalam pembelajaran optika memiliki kategori cukup dengan rincian sebagai berikut: (1) Persentase mahasiswa yang memiliki kemampuan berpikir tingkat tinggi kategori sangat baik adalah sebesar 15,79\%, kategori baik sebesar 31,58\%, kategori cukup sebesar $42,11 \%$, dan kategori kurang sebesar $10,53 \%$; (2) Persentase kemampuan mahasiswa dalam menjawab soal tingkatan menganalisis sebesar $68,42 \%$, kemampuan mahasiswa dalam menjawab soal tingkatan mengevaluasi sebesar $57,89 \%$ dan sebesar $53,51 \%$ untuk kemampuan mahasiswa dalam menjawab soal tingkatan mencipta.
\end{abstract}

Kata-kata Kunci: kemampuan berpikir tingkat tinggi, optika, model problem based learning 


\section{PENDAHULUAN}

Kemampuan berfikir merupakan kegiatan penalaran yang reflektif, kritis, dan kreatif yang berorientasi pada suatu proses intelektual yang melibatkan pembentukan konsep (conceptualizing), aplikasi, analisis, menilai informasi yang terkumpul (sintesis) atau dihasilkan melalui pengamatan, pengalaman, refleksi, komunikasi sebagai landasan kepada suatu keyakinan (kepercayaan) dan tindakan (Iskandar, 2009: 86). Kemampuan berpikir sangat dibutuhkan dalam memecahkan permasalahan khususnya dalam fisika (Winarti, 2015: 19). Ada banyak konsep yang dipelajari di dalam fisika yang dapat dijumpai secara nyata dalam kehidupan sehari-hari, satu di antaranya adalah konsep optika. Karakteristik konsep optika yang bersifat abstrak sehingga memerlukan kemampuan berpikir tinggi untuk memahami teori-teori dan membandingkannya dengan gejala di kehidupan sehari-hari. Namun, berdasarkan analisis jawaban mahasiswa dalam menyelesaikan soal ujian akhir semester pada materi optika, hanya $20 \%$ mahasiswa saja yang mampu menyelesaikan soal pada tingkatan tinggi seperti menganalisis, mengevaluasi, dan mencipta.

Kurangnya kemampuan mahasiswa dalam menyelesaikan soal tingkat tinggi dikarenakan dalam proses pembelajaran kurang mengembangkan kemampuan berpikir mahasiswa tingkat tinggi padahal mahasiswa merupakan individu yang sudah pada tingkat perkembangan intelektual operasi formal tingkat tinggi (Krathwohl dan Anderson, 2001: 30). Proses pembelajaran lebih cenderung terfokus pada satu arah sehingga mahasiswa kurang menyadari proses berpikirnya sehingga proses belajar bermakna dan relevan kurang dapat tercapai. Hal ini sejalan dengan pendapat Suwardjono (2009: 1) bahwa mahasiswa menganggap dosen merupakan sumber pengetahuan utama dan yang ahli dalam bidangnya, mahasiswa hanya memperoleh catatan pengetahuan tanpa mengetahui proses dan pemahaman pengetahuan tersebut.

Kemampuan berpikir sangat penting dalam mendeskripsikan dan menjelaskan fenomena fisika. Kemampuan berpikir dapat dikategorikan sebagai: (a) secara akurat menggambarkan tentang fenomena alam, (b) penginderaan dan mengajukan pertanyaan tentang fenomena alam yang terjadi, (c) mengakui, menciptakan dan menyatakan hipotesis alternatifdan teori, (d) menghasilkan prediksilogis, (e) perencanaan dan melakukan eksperimen terkontrol untuk menguji hipotesis, (f) mengumpulkan, mengorganisir, dan menganalisa data eksperimental dan korelasional yang relevan, dan (g) menggambarkan dan menerapkan kesimpulan yang wajar (Lawson, 2002).

Menurut taksonomi Bloom yang telah direvisi proses kognitif terbagi menjadi kemampuan berpikir tingkat rendah (Lower Order Thinking) dan kemampuan berpikir tingkat tinggi (Higher Order Thinking). Kemampuan yang termasuk LOT adalah kemampuan mengingat (understand remember), memahami, dan menerapkan (apply), sedangkan HOT meliputi kemampuan menganalisis (analyze), mengevaluasi (evaluate), dan menciptakan (create) (Krathwohl dan Anderson, 2001: 30). Dengan demikian, kemampuan berpikir tingkat tinggi (Higher Order Thinking) meliputi kemampuan dalam menganalisis, mengevaluasi, dan menciptakan.

Menganalisis merupakan usaha untuk mengurai suatu materi menjadi bagian penyusunnya dan menentukan bagian hubungan antara bagian tersebut dengan materi tersebut secara keseluruhan. Pada kategori ini terdapat tiga sub kategori yaitu membedakan, mengorganisasi dan menghubungkan.

Mengevaluasi merupakan tindakan membuat suatu penilaian yang didasarkan pada kriteria dan standar tertentu. Pada kemampuan ini terdapat dua kategori yaitu kemampuan memeriksa dan mengkritik.

Menciptakan merupakan proses mengumpulkan sejumlah elemen tertentu menjadi satu kesatuan yang koheren dan fungsional. Pada kemampuan ini terdapat tiga sub kategori yaitu kemampuan memunculkan, merencanakan dan menghasilkan.

Kemampuan berpikir tingkat tinggi merupakan aspek penting dalam pengajaran dan pembelajaran. Kemampuan berpikir sesorang dapat mempengaruhi kemampuan pembelajaran, kecepatan dan efektivitas pembelajaran. Oleh karena itu, dalam proses pembelajaran sebaiknya memperhatikan kemampuan berpikir siswa. Siswa yang dilatih untuk berpikir menunjukkan dampak positif pada pengembangan pendidikan mereka (Yee dkk, 2011).

Model pembelajaran yang dipandang dapat membantu dan memfasilitasi untuk memudahkan mahasiswa dalam menguasai konsep fisika dan berlatih mengembangkan kemampuan berpikir 
tingkat tinggi satu diantaranya adalah model problem based learning. Penggunaan model problem based learning dipilih karena melihat dari penelitian terdahulu yang telah dilakukan menunjukkan hasil yang baik. Penelitian Kwek, Lye (2005), menunjukkan bahwa penggunaan metode Problem Posing dalam bentuk tugas dapat meningkatkan proses berpikir siswa, dalam pemahaman terhadap pembelajaran matematik.

Menurut Kamdi (2007: 77), Model Problem Based Learning (PBL) merupakan suatu model pembelajaran yang dapat melibatkan peserta didik untuk memecahkan masalah yang nyata melalui tahap-tahap metode ilmiah sehingga peserta didik dapat mempelajari pengetahuan yang berhubungan dengan masalah tersebut dan sekaligus memiliki keterampilan untuk memecahkan masalah yang nyata tersebut. Misalnya suatu fenomena alam, tongkat seolah-olah kelihatan patah saat dimasukkan di dalam air, uang logam yang diletakkan dalam sebuah gelas kosong jika dilihat pada posisi tertentu tidak terlihat tetapi ketika diisi air menjadi kelihatan. Dari contoh permasalahan nyata, jika diselesaikan secara nyata memungkinkan mahasiswa memahami konsep bukan sekedar menghafal konsep.

Beberapa penelitian tentang kemampuan berpikir tingkat tinggi telah pernah dilaksanakan. Penelitian Raudenbush dkk (1993) menyimpulkan bahwa pemahaman guru tentang kemampuan berpikir tingkat tinggi yang baik memberikan pengaruh yang signifikan untuk persiapan guru dalam mengajarkan materi pengembangan berpikir tingkat tinggi bagi siswanya. Lewy dkk (2009) berdasarkan hasil penelitiannya menyarankan agar guru menggunakan soal-soal berlevel kemampuan berpikir tingkat tinggi karena soal-soal tersebut memiliki efek potensial terhadap hasil tes kemampuan berpikir tingkat tinggi. Ulfa (2013) dalam penelitiannya disimpulkan bahwa kemampuan berpikir tingkat tinggi mahasiswa yang diajarkan dengan strategi pembelajaran berbasis masalah signifikan lebih tinggi dibandingkan dengan pembelajaran tradisional. Selain itu, penelitian yang dilakukan oleh Prasetyani dkk (2016) menyimpulkan bahwa kemampuan siswa dalam menyelesaikan soal higher order thinking setelah diajarkan menggunakan model pembelajaran berbasis masalah memiliki kriteria baik pada kemampuan menganalisis dan mengevaluasi dan kurang pada kemampuan mencipta.

Tujuan penelitian ini adalah untuk mendeskripsikan kemampuan berpikir tingkat tinggi mahasiswa (higher order thinking) dalam menyelesaikan soal konsep optika setelah diberikan pembelajaran dengan model problem based learning.

\section{METODE PENELITIAN}

Metode penelitian ini adalah metode deskriptif dengan pendekatan kuantitatif. Metode penelitian deskriptif digunakan karena dalam penelitian ini akan mendeskripsikan kemampuan berpikir tingkat tinggi mahasiswa dalam menyelesaikan soal materi optika setelah diterapkan pembelajaran melalui model problem based learning. Subjek dalam penelitian ini adalah seluruh mahasiswa semester II yang mengambil mata kuliah fisika dasar ii yang berjumlah 19 orang.

Teknik yang digunakan dalam pengambilan data yaitu teknik pengukuran. Alat ukur yang digunakan berupa tes berbentuk two tier multiple choice berjumlah delapan soal yang terdiri dari tingkatan menganalisis, mengevaluasi dan mencipta. Tes yang digunakan dalam pengambilan data terlebih dahulu diuji validitas dan reliabilitas tes. Berdasarkan analisis uji coba soal diketahui bahwa delapan soal dinyatakan valid dan reliabel. Adapun rincian soal tes disajikan pada TABEL 1. 
TABEL 1. Sebaran tes kemampuan berpikir tingkat tinggi berbentuk two tier multiple choice.

\begin{tabular}{cccc}
\hline No & Tingkatan Berpikir & Aspek & Jumlah Soal \\
\hline 1. & & Membedakan & 1 \\
2. & Menganalisis & Mengorganisasi & 1 \\
3. & & Menghubungkan & 1 \\
\hline 4. & Mengevaluasi & Memeriksa & 1 \\
5 & & Mengkritik & 1 \\
\hline 6. & & Memunculkan & 1 \\
7. & Mencipta & Merencanakan & 1 \\
8. & & Menghasilkan & 1 \\
\hline
\end{tabular}

Data skor jawaban mahasiswa dalam menyelesaikan soal higher order thinking (HOT) akan dianalisis menggunakan statistik deskriptif. Adapun langkah-langkah analisis yaitu (1) mengubah skor menjadi nilai, (2) mengkategorikan nilai kemampuan berpikir tingkat tinggi mahasiswa yang mengacu pada International Center for the Assesment of Higher Order Thinking (Prasetyani dkk, 2016) (TABEL 2) dan (TABEL 3) menentukan persentase kemampuan mahasiswa dalam menyelesaikan soal HOT berdasarkan tiap indikator.

TABEL 2. Kategori Kemampuan Berpikir Tingkat Tinggi Mahasiswa.

\begin{tabular}{cc}
\hline Nilai & Kategori \\
\hline $81-100$ & Sangat Baik \\
\hline $61-80$ & Baik \\
\hline $41-60$ & Cukup \\
\hline $21-40$ & Kurang \\
\hline $0-20$ & Sangat Kurang \\
\hline
\end{tabular}

\section{HASIL DAN PEMBAHASAN}

Data kemampuan berpikir tingkat tinggi mahasiswa dalam menyelesaikan soal materi optika setelah diberikan pembelajaran dengan model problem based learning disajikan pada TABEL 3 berikut.

TABEL 3. Data Kemampuan Berpikir Tingkat Tinggi Mahasiswa dalam Menyelesaikan Soal Materi Optik.

\begin{tabular}{cc}
\hline Aspek & Nilai \\
\hline Nilai Maksimum & 81 \\
\hline Nilai Minimum & 38 \\
\hline Rata-Rata Nilai & 60 \\
\hline Standar Deviasi & 14 \\
\hline
\end{tabular}

Berdasarkan TABEL 3 diketahui bahwa nilai tertinggi yang diperoleh mahasiswa dalam menyelesaikan soal HOT yaitu 81 dan nilai terendah 38. Rata-rata nilai sebesar 60 dengan standar deviasi sebesar 14. Hal ini menunjukkan bahwa rata-rata nilai kemampuan berpikir tingkat tinggi mahasiswa masih tergolong dalam kriteria cukup.

TABEL 4 menyajikan persentase kemampuan berpikir tingkat tinggi mahasiswa dalam menyelesaikan soal materi optika berdasarkan nilai. 
TABEL 4. Persentase Kemampuan Berpikir Tingkat Tinggi Mahasiswa dalam Menyelesaikan Soal HOT Materi Optika.

\begin{tabular}{cccc}
\hline Nilai & Kategori & Frekuensi & Persentase (\%) \\
\hline $81-100$ & Sangat Baik & 3 & 15,79 \\
\hline $61-80$ & Baik & 6 & 31,58 \\
\hline $41-60$ & Cukup & 8 & 42,11 \\
\hline $21-40$ & Kurang & 2 & 10,53 \\
\hline $0-20$ & Sangat Kurang & 0 & 0,00 \\
\hline & Jumlah & 19 & 100,00 \\
\hline
\end{tabular}

Dari TABEL 4, diketahui bahwa frekuensi terbanyak adalah mahasiswa dengan kategori kemampuan berpikir tingkat tinggi cukup yaitu sebesar $42,11 \%$ dan tidak ada mahasiswa yang berkategori kemampuan berpikir tingkat tinggi sangat kurang (0\%). Hal ini menunjukkan bahwa ratarata mahasiswa memiliki kemampuan berpikir tingkat tinggi cukup.

Selanjutnya persentase kemampuan mahasiswa dalam menjawab soal HOT berdasarkan tiap indikator disajikan pada TABEL 5 berikut.

TABEL 5. Persentese kemampuan mahasiswa dalam menjawab soal HOT berdasarkan tiap indikator.

\begin{tabular}{cc}
\hline Indikator & Persentase (\%) \\
\hline Menganalisis & 68,42 \\
Mengevaluasi & 57,89 \\
Mencipta & 53,51 \\
\hline
\end{tabular}

Dari TABEL 5, tampak bahwa persentase kemampuan mahasiswa dalam menyelesaikan soal HOT terbesar yaitu pada indikator menganalisis dan persentase terkecil yaitu pada indikator mencipta.

Pembelajaran dilaksanakan sesuai dengan langkah-langkah model problem based learning yaitu (1) orientasi mahasiswa pada masalah, (2) menggorganisasikan siswa untuk belajar, (3) membimbing penyelidikan individu dan kelompok, (4) mengembangkan dan menyajikan hasil karya dan (5) menganalisis dan mengevaluasi proses pemecahan masalah. Selama proses pembelajaran berlangsung dosen hanya berperan sebagai fasilitator sehingga pembelajaran lebih terfokus pada mahasiswa. Mahasiswa dilatih untuk mengembangkan proses berpikir analisis yaitu saat mahasiswa diminta menyelesaikan masalah yang diberikan di awal pembelajaran, tampak bahwa mahasiswa secara berkelompok aktif berdiskusi dengan bantuan Lembar Keja Mahasiswa (LKM) yang diberikan oleh dosen. Hal inilah yang membuat mahasiswa mampu menyelesaikan soal pada kategori menganalisis. Berdasarkan analisis lembar jawaban mahasiswa terlihat bahwa mahasiswa mampu mengurai informasi, dengan menuliskan apa yang diketahui dan ditanya sesuai dengan yang dimaksud oleh soal, mampu menggunakan konsep untuk menentukan langkah penyelesaian yang tepat. Hal ini seperti yang diungkapkan oleh Prastyani dkk (2016) bahwa indikator menganalisis permasalahan terlihat dari penyelesaian yang ditulis siswa, yaitu mampu mengurai informasi, menggunakan konsep, serta langkah penyelesaian yang tepat. Apabila analisis permasalahan yang dilakukan benar, penyelesaian yang ditulis mengarah pada penyelesaian yang dimaksud pada soal, dan langkah penyelesaian dilakukan hingga selesai, maka siswa tersebut dapat dikatakan mampu menganalisis permasalahan. Kemampuan mahasiswa dalam menyelesaikan soal kategori mengevaluasi lebih rendah dibandingkan kemampuan mahasiswa dalam menyelesaikan soal kategori menganalisis dikarenakan tidak semua mahasiswa mampu memberikan penilaian terhadap solusi yang diberikan berdasarkan kriteria yang cocok. Mengevaluasi dapat dilakukan apabila mahasiswa mampu merencanakan dan melaksanakan perencanaan penyelesaian permasalahan dengan tepat, memahami maksud pertanyaan dengan benar, serta memberikan alasan/bukti yang tepat sehingga jawaban yang dituliskan akan menjawab pertanyaan yang dimaksud. 
Kemampuan mahasiswa dalam menyelesaikan soal kategori mencipta paling rendah dibandingkan dua kategori yang lainnya yaitu menganalisis dan mengevaluasi. Pada kemampuan ini mahasiswa dapat memadukan bagian-bagian untuk membentuk sesuatu yang baru dan koheren atau dapat membuat suatu produk yang orisinal. Mahasiswa dikatakan mampu mencipta apabila mahasiswa dapat menganalisis permasalahan dengan tepat, menentukan ide awal dengan tepat, serta memberikan bukti/alasan yang tepat.

Berdasarkan temuan penelitian yang telah dilakukan, dapat diketahui bahwa model problem based learning yang digunakan belum sepenuhnya mampu meningkatkan kemampuan berpikir tingkat tinggi mahasiswa terutama untuk kategori mengevaluasi dan mencipta. Hal ini dikarenakan pada proses pembelajaran, yaitu pada tahapan membimbing penyelidikan kelompok, keterlibatan dosen dalam membantu mahasiswa untuk melakukan penyelidikan masih terlalu banyak sehingga kurang menumbuhkan kemandirian mahasiswa dalam melakukan penyelidikan guna memecahkan masalah. Selanjutnya pada fase mengembangkan dan menyajikan informasi, hanya sebagian kecil mahasiswa saja yang aktif dalam kegiatan tersebut. Hal yang sama juga dirasakan pada fase mengevaluasi proses pemecahan masalah, mahasiswa yang terlihat aktif hanya mahasiswa yang kriteria kemampuan berpikir tingkat tinggi baik. Hal ini dikarenakan mahasiswa yang merasa kurang pandai takut dan malu untuk menyampaikan pendapatnya. Oleh karena itu, dalam pembelajaran dengan menggunakan model problem based learning harus memperhatikan karakteristik dari model itu sendiri. Adapun karakteristik model problem based learning menurut Sofyan (2016: 263) antara lain: (1) siswa harus peka terhadap lingkungan belajarnya, (2) simulasi problem yang digunakan hendaknya berbentuk illstructured, dan memancing penemuan bebas (free for inquiry), (3) pembelajaran diintegrasikan dalam berbagai subjek, (4) pentingnya kolaborasi, (4) pembelajaran hendaknya menumbuhkan kemandirian siswa dalam memecahkan masalah, (5) aktivitas pemecahan masalah hendaknya mewakili pada situasi nyata, (6) penilaian hendaknya mengungkap kemajuan siswa dalam mencapai tujuan dalam pemecahan masalah, (7) PBL hendaknya merupakan dasar dari kurikulum bukan hanya pembelajaran. Selain itu, pada saat penyelidikan, sebaiknya dalam menemukan proses pemecahan masalah dapat dilakukan dengan membuat peta konsep secara berkelompok. Hal ini dilakukan agar mempermudah mahasiswa dalam menemukan pemecahan masalah serta dapat mengembangkan kemampuan berpikir mahasiswa. Hal ini diperkuat dari hasil penelitian yang dilakukan Muhlisin, dkk (2016: 15), disimpulkan bahwa membuat peta pikiran secara berkelompok mampu mengurangi kecemasan belajar, mampu membuat keberanian belajar sehingga siswa mampu mengembangkan pemikiran, dan dapat meningkatkan kemampuan mahasiswa dalam menghubungkan sesuatu beserta alasannya, asumsi dan pada akhirnya dapat membuat kesimpulan. Hasil penelitian serupa juga ditemukan oleh Jena (2012); Nilson dkk., (2014) bahwa peta pikiran yang dibuat secara kolaboratif akan membuat belajar lebih bermakna, mengurangi kecemasan diri, dan memperbaiki pembelajaran partisipasi untuk bisa mengidentifikasi alasan, alternatif, dan kesimpulan.

\section{SIMPULAN}

Berdasarkan penelitian yang telah dilakukan, dapat disimpulkan bahwa (1) Persentase mahasiswa yang memiliki kemampuan berpikir tingkat tinggi kategori sangat baik adalah sebesar 15,79\%; kategori baik sebesar 31,58\%; kategori cukup sebesar 42,11\%; dan kategori kurang sebesar 10,53\% (2) Persentase kemampuan mahasiswa dalam menjawab soal tingkatan menganalisis sebesar $68,42 \%$, kemampuan mahasiswa dalam menjawab soal tingkatan mengevaluasi sebesar 57,89\% dan sebesar $53,51 \%$ untuk kemampuan mahasiswa dalam menjawab soal tingkatan mencipta.

Hasil penelitian menunjukkan bahwa melalui penerapan model problem based learning dalam pembelajaran fisika khususnya materi optika dapat mengembangkan kemampuan berpikir tingkat tinggi mahasiswa pada tingkatan menganalisis, mengevaluasi dan mencipta. Untuk itu, peneliti merekomendasikan agar dosen dapat menerapkan model problem based learning dalam pembelajaran materi fisika. Selain itu, agar pelaksanaan pembelajaran dengan model problem based learning dapat berjalan sesuai dengan tahap-tahapannya maka peneliti menyarankan yaitu: (1) Adanya panduan yang jelas terkait langkah-langkah problem based learning yang dibuat oleh dosen sehingga dosen mengetahui kegiatan-kegiatan yang akan dilakukan selama proses pembelajaran, (2) Mensosialisasikan langkah-langkah problem based learning kepada mahasiswa 
sebelum pembelajaran berlangsung sehingga mahasiswa dapat mempelajarinya terlebih dahulu, (3) mengurangi keterlibatan dosen dalam pembelajaran terutama dalam tahapan membimbing penyelidikan kelompok, (4) Membuat peta konsep (mind mapping) secara berkelompok dengan langkah yang dimulai dari menganalisis masalah, pemecahan masalah sampai membuat kesimpulan.

\section{UCAPAN TERIMA KASIH}

Penelitian ini dibiayai oleh KEMENRISTEKDIKTI sehingga peneliti mengucapkan terima kasih yang sebesar-besarnya kepada KEMENRISTEKDIKTI atas bantuan yang diberikan. Selain itu peneliti juga mengucapkan terima kasih kepada IKIP PGRI Pontianak yang telah memberikan dukungan sehingga penelitian ini bisa terlaksana.

\section{REFERENSI}

Iskandar. 2009. Psikologi Pendidikan. Jakarta: Gaung Persada Pers.

Jena, A. (2012). Does Constructivist Approach Applicable Through Concept Maps to Achieve Meaningful Learning in Science. Asia-Pacific Forum on Science Learning and Teaching. 13(1).1-23.

Kamdi, W. 2007. Model-Model Pembelajaran Inovatif. Malang: Universitas Negeri Malang.

Krathwohl, D. R. \&Anderson, L. W. (Eds.). 2001. A taxonomy for learning, teaching, andassessing: A revision of Bloom's taxonomy of educational objectives. New York: Longman.

Lawson, A. E. 2002. Science teaching and Developmentof thinking. Wadsworth/Thomson Noeng.

Lewy., Zulkardi., dan Aisyah N. 2009. Pengembangan Soal Untuk Mengukur Kemampuan Berpikir Tingkat Tinggi Pokok Bahasan Barisan dan Deret Bilangan di Kelas IX Akselerasi SMP Xaverius Maria Palembang. Jurnal Pendidikan Matematika. 3 (2). 4-6.

Muhlisin, A., Susilo, H., Amin, M., Rohman, F. 2016. Improving critical thinking skills of college students through RMS model for learning basic concepts in science. Asia-Pacific Forum on Science Learning and Teaching. 17 (1). 1-24.

Nilson, C., Fetherston, C., \& McMurray, A. (2014). Developing Children's Critical Thinking through Creative Arts Exposure: An Application of Ennis's Super-streamlined Critical Thinking Framework. The International Journal of Arts Education. 8. 29-45.

Prasetyani, E., Hartono, Y., Susanti, E. 2016. Kemampuan Berpikir Tingkat Tinggi Siswa Kelas XI dalam Pembelajaran Trigonometri Berbasis Masalah diSMA Negeri 18 Palembang. Jurnal Gantang Pendidikan Matematika FKIP-UMRAH. 1 (1). 31-40.

Raudenbush, Stephen W., Brian Rowan, and Yuk Fai Cheong. "Higher order instructional goals in secondary schools: Class, teacher, and school influences." American Educational Research Journal 30.3 (1993): 523-553.

Sofyan, H. 2016. Pembelajaran Problem Based Learning dalam Implementasi Kurikulum 2013 di SMK. Jurnal Pendidikan Vokasi. 6 (3). 260-271.

Suwardjono. 2009. Revolusi Paradigma Pembelajaran Perguruan Tinggi Dari Penguliahan ke Pembelajaran. (htttp://inparametric.com/bhinablog/download/Artikel1.pdf, diakses 30 Desember 2015).

Ulfa, W., dkk. 2013. Pengaruh Strategi Pembelajaran Berbasis Masalah Terhadap Kemampuan Berpikir Tingkat Tinggi (Menganalisis, Mengevaluasi, Mencipta) dan Keterampilan Proses Sains Mahasiswa STIPAP LPP Medan. Jurnal UNIMED. 1-5. 
Winarti. 2015. Profil Kemampuan Berpikir Analisis dan Evaluasi Mahasiswa dalam Mengerjakan Soal Konsep Kalor. Jurnal Inovasi dan Pembelajaran Fisika. 2 (1). 19-24.

Yee, M. H., Widad B. O., Jailani B. M.Y. 2011. The Level of Marzano Higher Order Thinking Skills Among Technical Education Students, International. Jurnal Social Science and Humanity. 1 (2). 